- FINANSE I PRAWO FINANSOWE.

- Journal of Finance and Financial Law •

Czerwiec/June 2018 • vol. 2(18): 9-24

https://doi.org/10.18778/2391-6478.2.18.02

\title{
SYSTEMY GWARANTOWANIA \\ DEPOZYTÓW BANKOWYCH NA ŚWIECIE \\ - ANALIZA PORÓWNAWCZA
}

Mateusz Dadej

Koło Naukowe Finansów Międzynarodowych,Wydział Ekonomiczny

Uniwersytet Gdański

\section{Streszczenie}

Celem niniejszego artykułu jest przedstawienie rodzajów i form systemów gwarancji depozytów, przyjętych na całym świecie oraz ich problematyki. W artykule przedstawiono teoretyczne aspekty funkcjonowania systemów gwarancji depozytów, dające podstawę dla czytelnika do oceny przyjętych rozwiązań opisanych $w$ dalszej części artykułu. Scharakteryzowano przyjęte formy systemów gwarancji depozytów, takie jak: rodzaj sformalizowania, struktura i administracja, sprawowana funkcja, finansowanie oraz poziom gwarancji depozytów. W każdym przedstawionym rozwiązaniu dodatkowo podano jego implikacje dla sektora finansowego oraz kraje, w których został przyjęty. Dane empiryczne z banku światowego oraz IADI, w wielu przypadkach zostały zaktualizowane o informacje pochodzące $z$ oficjalnych stron lub dokumentów systemów gwarancji depozytów lub instytucji, w których skład one wchodzą.

Słowa kluczowe: bankowość, systemy gwarancji depozytów, gwarancja depozytów, pokusa nadużycia, stabilność sektora bankowego, analiza porównawcza, depozyt bankowy, ochrona konsumenta, usługi bankowe, teoria finansów.

JEL Class: G21, G22. 


\section{WPROWADZENIE}

System bankowy jest jedną z najistotniejszych części gospodarki. Skutki wadliwej struktury działania lub aspektów koniunkturalnych tego systemu są odczuwalne w każdej części gospodarki danego kraju. Jak to zazwyczaj bywa, najbardziej poszkodowany zostaje konsument. Na potrzeby ochrony stabilności systemu bankowego na przestrzeni ostatniego wieku powstał szereg instytucji tworzących tak zwaną siatkę bezpieczeństwa finansowego - Safety net. Jedną z tych instytucji, na którą autor chciałby zwrócić szczególną uwagę czytelnika jest system gwarancji depozytów oraz jego zróżnicowana adaptacja na świecie. Główną funkcją tego systemu jest ochrona deponentów w przypadku niewypłacalności instytucji finansowych przechowujących ten depozyt.

Celem niniejszego artykułu jest przedstawienie rodzajów i form systemów gwarancji depozytów przyjętych na świecie oraz wskazanie konsekwencji dla sektora finansowego i uczestniczących w nim konsumentów, płynących $\mathrm{z}$ adaptacji konkretnych wariantów systemów gwarantujących depozyty. $\mathrm{Na}$ potrzeby niniejszego artykułu przyjęto hipotezę, że państwa wraz z rozwojem gospodarczym przyjmują odmienne rozwiązania systemów gwarancji depozytów, szczególnie w przypadku krajów rozwiniętych.

Artykuł opiera się na badaniach literaturowych, części empirycznej na podstawie informacji podanych na oficjalnych stronach systemów gwarancji depozytów różnych krajów lub podmiotów, w których skład wchodzą oraz danych udostępnionych przez bank światowy i międzynarodowe stowarzyszenie gwarantów depozytów (IADI).

Metody badawcze wykorzystane w artykule to: analiza statystyczna, metoda literaturowa, metoda monograficzna oraz metoda badania dokumentów.

\section{TEORETYCZNE ASPEKTY FUNKCJONOWANIA SYSTEMÓW GWARANCJI DEPOZYTÓW}

\subsection{Stabilność oraz zaufanie do systemu bankowego}

Instytucje bankowe powinny charakteryzować się nienaganną opinią. Jest to istotne przede wszystkim ze względu na stabilność systemu bankowego. Tak jak słusznie zauważył John M. Keynes racjonalne działania ludzi z mikroekonomicznego punktu widzenia nie muszą być racjonalne w ujęciu makroekonomicznym [Keynes 1936]. Zgodnym z tym twierdzeniem jest fenomen paniki bankowej (ang. bank run) występujący, gdy duża część klientów banku pragnie wycofać swoje depozyty z danej instytucji, z obawy o jej wypłacalność [Samuelson i Nordhaus 2012]. Istotę systemów gwarancji depozytów w kontekście 
paniki podkreśla model Diamonda-Dybviga. Przedstawiają oni ten fenomen na płaszczyźnie teorii gier, dziedziny matematyki powszechnie wykorzystywanej w ekonomii. Graczami są klienci banku, którzy lokują w nim swoje pieniądze w zamian dostając wypłatę. Jest to dobry przypadek równowagi Nasha (oraz efektywny w sensie Pareto). Jednakże w przypadku, gdy bank wpada w zagrożenie bankructwem, klienci wypłacają gotówkę. Tworzy się wtedy zła równowaga, skutkująca bankructwem banku oraz w wyniku tego mniejszą wypłatą dla graczy [Diamond 1983].

Tabela 1 przedstawia macierz symetrycznych wypłat dwuosobowej gry z czystymi strategiami. Kolumny reprezentują wybór (wypłata lub trzymanie depozytu w banku) deponenta $\mathrm{nr} 1$, wiersze natomiast deponenta $\mathrm{nr} 2$. Wypłaty zależą od wyboru przeciwnego gracza oraz sumy gry, tj. wartości depozytów w banku. Są 4 rodzaje wypłat:

- C - Likwidacja banku, deponent dostaje 1/3 wartości depozytu.

- L - Likwidacja depozytu oraz banku, deponent traci wszystko.

- N-Bank działa sprawnie, obaj gracze dostają całkowitą wartość depozytu.

- Z - Wypłata przed likwidacją banku, deponent dostaje 2/3 wartości depozytu.

Tabela 1. Konflikt deponentów

\begin{tabular}{|l|c|c|}
\hline & Wypłata gotówki & Pozostawienie depozytu \\
\hline Wypłata gotówki & $\mathrm{C}, \mathrm{C}$ & Z, L \\
\hline Pozostawienie depozytu & $\mathrm{L}, \mathrm{Z}$ & $\mathrm{N}, \mathrm{N}$ \\
\hline
\end{tabular}

Źródło: opracowanie własne na podstawie: Diamond [1983].

Problem ten był szczególnie dotkliwy, kiedy banki nie były poddawane regulacjom (free banking), olbrzymie znaczenie miała reputacja banku. Wystarczyła plotka, aby zainicjować wyprowadzanie środków przez deponentów [Baka (red.) 2005]. W aktualnej dekadzie nieczęsto można spotkać się ze zjawiskiem paniki bankowej. Niemniej jednak, jak pokazuje przykład ostatniego run'u na bank Northern Rock [www1] lub Bank of East Asia [www2], zagrożenie to jest jak najbardziej realne, szczególnie podczas kryzysu gospodarczego, gdy zaufanie publiczne do instytucji finansowych słabnie. Jak dobrze zauważył Ben Bernanke [Bernanke 1995], paniki bankowe mają zdecydowanie negatywny wpływ także na realną sferę gospodarki, między innymi zmniejszając produkt krajowy oraz zwiększając bezrobocie.

Systemy Gwarancji depozytów eliminują ryzyko utraty depozytu oraz minimalizują eskalację paniki bankowej poprzez gwarancje wypłaty depozytu. Dzięki tej gwarancji szanse wypłaty pełnego depozytu nie są zależne od innych deponentów i tym samym bankructwa banku. 


\subsection{Wpływ systemów na podejmowanie decyzji banku}

Nie trudno jest sztucznie zniekształcić naturalne procesy podejmowania decyzji przez podmioty rynkowe. Kwestia ingerencji państwa na rynku jest gorącym tematem dyskusji od początków istnienia nauk ekonomicznych. Skutki nieraz przejawiają sie w ograniczaniu części rynku, które wspierają rozwój gospodarczy lub stymulowaniem tych które ten rozwój ograniczają. Niemniej jednak, oba przypadki mogą charakteryzować się nieefektywną alokacją zasobów. Ten sam dylemat, tj. interwencjonizmu, możemy dostrzec w dyskusji na temat sensu działania systemów gwarancji depozytów.

Instytucje finansowe objęte tymi systemami mogą przejawiać tak zwaną pokusę nadużycia (ang. moral hazard), czyli podwyższanie podatności na ryzyko, od którego dany podmiot jest ubezpieczony (nie ponosi jego negatywnych skutków). W przypadku banków może się to objawiać zwiększaniem akcji kredytowej dla podmiotów o niższej zdolności kredytowej, ze względu na fakt, iż niepowodzenie spowodowane daną polityką kredytową zostanie zrekompensowane publiczną pomocą finansową. Pokusa nadużycia jest najpoważniejszym zagrożeniem istnienia systemów gwarancji depozytów. Jednakże aktualny konsensus, przejawiający sie w globalnym trendzie adaptacji systemów (wykres 1) pokazuje, że kwestia pokusy nadużycia sprowadza sie jedynie do próby jej ograniczenia.

\subsection{Przeciwdziałanie efektu zarażania}

Sektor bankowy charakteryzuje się wyjątkową podatnością podmiotów na warunki wewnątrz sektora. Jest to wyjątkowy przykład systemu naczyń połączonych, ponieważ - paradoksalnie - nieraz bankructwo konkurencji może skutkować pogorszeniem się sytuacji banków działających bezbłędnie. Efekt zarażania stanowi tego rodzaju zagrożenie. Przejawia się on tym, że negatywna sytuacja jednego lub grupy banków wywołuje zaburzenia wśród innych banków.

Wymienia się 3 rodzaje źródeł efektu zarażania [Lubiński 2014]. Pierwszym, wspomnianym wcześniej, jest panika bankowa. Powstaje na skutek pogorszenia się opinii na temat banku, przez co na reputacji tracą kolejne instytucje bankowe, z których deponenci, także ze strachu przed upadłością, wycofują swoje środki. W kolejnym przypadku dochodzi do upadku dużego banku, skutkując spadkiem wartości aktywów przez niego posiadanych. Inne banki wpadają w kłopoty finansowe $\mathrm{z}$ powodu spadku wartości posiadanych aktywów tego samego rodzaju co banku upadającego. Ostatnim źródłem są pożyczki międzybankowe z udziałem upadających banków. Jeśli bank upadnie, w zależności od jego aktywności na rynku kredytów międzybankowych, banki będą musiały 
uznać kredyty mu przyznane jako zagrożone, tym samym pogarszając swoje wyniki finansowe i poddając się ryzyku upadłości. Każdy z podanych przypadków zagraża kolejnym podmiotom - przypomina to efekt równi pochyłej.

Systemy gwarancji depozytów wspierając pewność w bezpieczeństwo ulokowanych w banku środków, powstrzymują pierwotne przyczyny paniki bankowej oraz przeciwdziałają dalszej ich eskalacji wśród reszty podmiotów sektora bankowego.

\subsection{Asymetria informacji wśród deponentów}

Jakakolwiek forma inwestycji, a nawet działalności gospodarczej, może się wiązać z niedoborem informacji przynajmniej jednej ze stron. Zmniejszenie tak zwanej asymetrii informacji, czyli sytuacji, w której jedna ze stron posiada większy zakres informacji od strony przeciwnej, pozwala unikać nieprzewidzianych strat oraz podejmować bezpieczniejsze decyzje w życiu codziennym.

Obowiązki informacyjne instytucji bankowych są oczywiście wystarczająco rzetelne, moga jednak przysparzać pewnych kłopotów ich klientom, w szczególności klientom detalicznym, którzy nie posiadają - w przeciwieństwie do klientów korporacyjnych - odpowiedniego sztabu analityków finansowych. Wystarczy sobie wyobrazić jak działałby sektor bankowy, gdyby każda osoba przed wyborem banku musiała sprawdzać jego kondycję finansową oraz powtarzać ten proces co pół roku. Jak pokazują doświadczenia z ostatniego kryzysu finansowego, w niektórych przypadkach nawet dokładne sprawdzenie prawdopodobieństwa upadłości banku nie gwarantuje tego, że nie zawiesi on wypłacania depozytów z dnia na dzień. Systemy gwarancji depozytów być może nie zmniejszają asymetrii informacji, natomiast dzięki nim ta zawodność rynku nie jest już tak istotnym problemem dla klientów banku.

\section{CHARAKTERYSTYKA SYSTEMÓW GWARANCJI DEPOZYTÓW}

\subsection{Rodzaj sformalizowania}

Jednym z podstawowych podziałów systemów gwarancji depozytów jest ich stopień sformalizowania oraz jawności. Nieformalne systemy gwarancji, czyli systemy typu implicite, przejawiają się kompletną dyskrecjonalnością w gwarantowaniu depozytów przez organy sprawujące nad nimi kontrolę. Wiąże się to z niepewnością wśród instytucji przyjmujących depozyty oraz deponentów odnośnie bezpieczeństwa powierzonych środków. W praktyce przejawiają się one 
bezpośrednią pomocą publiczną (ang. bailout) lub nacjonalizacją instytucji przyjmującej depozyty.

Od dawna zyskujące na popularności jest przyjmowanie systemów explicit, czyli w pełni uregulowanych instytucji administrowanych publicznie lub prywatnie. Posiadają one jasne i szeroko opisane zasady ochrony, między innymi poziom pokrycia, listę podmiotów objętych gwarancją oraz rodzaj chronionych depozytów. Systemy takie są wyjątkowo wygodne i przejrzyste dla deponentów, którzy w przypadku bankructwa instytucji, której powierzyli środki, nie muszą w niepewności czekać na interwencję ze strony państwa. Jednakże, jak wskazują A. Demirguc-Kunt oraz E. Detragiache [2000], ta koncepcja systemów gwarancji potrafi zachwiać dyscyplinę podmiotów sektora bankowego bardziej niż systemy typu implicite, szczególnie w państwach o słabo rozwiniętej strukturze regulacyjno-instytucjonalnej.

Autor zgadza się ze stanowiskiem A. Demirgüç-Kunt i in. [2006], że każdy kraj bez jasno przedstawionego i uregulowanego systemu (explicit) posiada de facto system typu implicite, co wynika z doświadczenia problemów sektora bankowego. W przypadku jakiegokolwiek zagrożenia niewypłaceniem depozytów, państwo ugina się pod presją deponentów i pomaga instytucji spłacić zobowiązania.

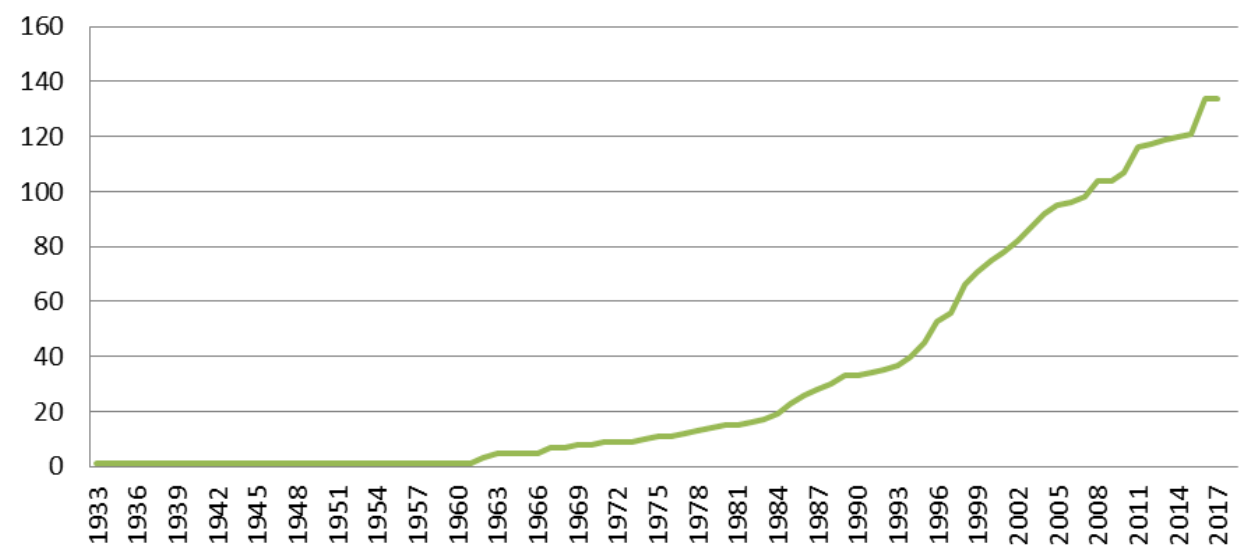

Wykres 1. Liczba państw z przyjętym systemem gwarancji depozytów typu explicite od 1933 do 2017 roku

Źródło: opracowanie własne na podstawie danych banku światowego, IADI [2016], uzupełnione o informacje $\mathrm{z}$ oficjalnych stron oraz dokumentów funduszy gwarancyjnych depozytów [Deposit Insurance Dataset/World Bank, 2013; www 3; www4; National Assembly of Pakistan, 2016; Modan i Hassan 2015; IMF 2016 (16/96); IMF, Mozambique: Fiscal Transparency Evaluation; Monetary Authority of Brunei Darussalam [2010]. 
Aktualnie, normą wśród państw jest posiadanie sformalizowanego systemu gwarancji depozytów. Aż 72\% stanowią systemy typu explicit, ze znaczną przewagą krajów rozwiniętych. Reszta państw w większości nie ma wystarczająco rozwiniętego systemu bankowego, żeby pozwolić sobie na tego rodzaju instytucje (m.in. Belize, Dżibuti, Kiribati i Somalia) i z pełną świadomością rezygnują z przyjmowania takich systemów (Nowa Zelandia i Egipt) lub są w trakcie tworzenia systemu explicit (Izrael, R.P.A., Z.E.A. lub Arabia Saudyjska) [www3, IADI 2016].

\subsection{Struktura i administracja}

Systemy typu explicite, które są warte szczególnej uwagi ze względu na stopień zróżnicowania przyjętych koncepcji, nie powstają wyłącznie z inicjatywy rządu. W przeciwieństwie do reszty instytucji wchodzących w skład siatki bezpieczeństwa, systemy gwarancji depozytów niekiedy tworzone są przez podmioty prywatne. Najlepszym tego przykładem jest powołanie funduszu ochrony depozytów w 1976 roku przez stowarzyszenie banków niemieckich (niem. Bundesverband Deutscher Banken). Fundusz ten działa do dzisiaj. Tego rodzaju inicjatywy sektora prywatnego pokazują faktyczny sens istnienia systemów ochrony depozytów, nie tylko jako ochrony konsumenta, ograniczającej działalność gospodarczą, ale także możliwość rozwoju inkluzywnego, na którym zyskuje tak samo konsument, jak i sektor bankowy.

Poza sposobem utworzenia systemów gwarancji depozytów, prywatne może być także administrowanie nim. Przejawia się to najczęściej wśród państw z bardzo dobrze rozwiniętym sektorem bankowym, na przykład Niemiec, Szwajcarii i Luksemburgu, głównie ze względu na lepszą dyscyplinę banków oraz podwyższone koszty działalności funduszu gwarancyjnego. Zagrożeniem w tym przypadku może być skłonność administratorów kierujących bankami do zmniejszenia finansowania funduszu gwarancyjnego [Kroszner i Stratmann 1998], skutkujące podwyższeniem ryzyka konsumenta. Jednakże najczęstszym wariantem, między innymi przyjętym w Polsce, jest administracja publiczna, kierowana wyłącznie przez reprezentantów rządu lub podmiotu publicznego, w którego skład wchodzi dany fundusz gwarancji depozytów. Popularność tej adaptacji jest bezpośrednio wynikiem zwyczaju publicznej inicjatywy stworzenia systemu gwarancji depozytów. Powszechne jest także powołanie publiczno-prywatnej administracji, przyjęte w takich krajach jak Japonia, Belgia czy Węgry [www5], w której kierownicy banków oraz urzędnicy państwowi wspólnie podejmują decyzje, oraz dzielą między siebie kompetencje. To rozwiązanie jest wyjątkowo praktycznym kompromisem, w którym chęci maksymalizowania zysku przez banki nie będą skutkowały zagrożeniem dla konsumenta. Według 
danych z 2013 roku 66\% systemów było kierowanych przez władzę publiczną, $11 \%$ wyłącznie prywatnie oraz $22 \%$ stanowiły administracje publiczno-prywatne [Deposit Insurance dataset/World Bank 2013].

Struktura zorganizowania systemów gwarancji depozytów może również różnić się w zależności od przyjętych koncepcji. Stworzenie oddzielnego podmiotu lub powołanie funduszu wewnątrz istniejącej instytucji publicznej, posiada mniejsze implikacje odnośnie efektywności prowadzenia działalności gwarantującej depozyty. Instytucje tworzące wewnątrz swojej struktury fundusz gwarancyjny to najczęściej banki centralne (zazwyczaj w krajach rozwijających się z pominięciem Irlandii, Słowenii i San Marino), instytucje sprawujące nadzór nad sektorem finansowym (Australia i Kanada) oraz ministerstwo finansów (Belgia i Kolumbia) [IADI 2016]. Wybór podmiotu może być istotny głównie ze względu na wyznaczenie winnego za ewentualne błędy w działalności systemu gwarancji depozytów oraz poniesienie przez niego adekwatnych konsekwencji. Aż 77,2\% krajów posiada oddzielny podmiot gwarantujący depozyty [Deposit Insurance dataset/World Bank 2013; www10], chociaż przez ostatnie 5 lat udział spadł o około 9 p.p., głównie ze względu na dużą liczbę państw Afryki, przyjmującą sformalizowane systemy gwarancji depozytów.

\subsection{Sprawowana funkcja}

Zasadniczym celem systemów gwarancji depozytów, jak można wywnioskować z nazwy, jest ochrona depozytariuszy przed utratą środków powierzonych instytucjom finansowym, natomiast sposób, w który ten cel jest osiągany oraz obowiązki odnośnie stabilności sektora są bardzo zróżnicowane.

Ze wszystkich sposobów kategoryzowania funkcji sprawowanej przez systemy gwarancji depozytów, w literaturze przyjął się następujący ich podział [Pawlikowski 2005]:

- „Paybox” - Jest fundamentalną i nierozłączną funkcją systemów gwarancji depozytów typu explicite. Polega wyłącznie na zbieraniu funduszy od podmiotów objętych gwarancją, w ramach pomocy depozytariuszom stojącym w niebezpieczeństwie bankructwa instytucji, której swoje depozyty powierzyli. Tego rodzaju funkcje spełniają między innymi fundusze gwarancyjne w Słowacji oraz Księstwie Liechtensteinu [www6].

- „Risk minimiser” - Oznacza system z poszerzonym zakresem uprawnień poza samą gwarancją depozytów, tj. zmniejsza ryzyko bankructwa lub nadzoruje sektor bankowy. Kraje, które przyjęły tego rodzaju system to przykładowo Norwegia oraz Peru [www7].

Dostępne formy wsparcia podmiotów zagrożonych niewypłacalnością potrafią być przydatne $\mathrm{w}$ thumieniu problemu u jego podstaw, w przeciwieństwie 
do zwalczania jego skutków. W zależności od systemu gwarancji depozytów mogą one mieć dowolny ich zestaw lub być z góry wyznaczone. Najpopularniejsze $\mathrm{z}$ tych instrumentów to: kredyt udzielany na warunkach bardziej opłacalnych niż rynkowe, zorganizowanie fuzji lub przejęcia przez poprawnie działający podmiot, utworzenie banku pomostowego (ang. bridge bank), czyli instytucji kontynuującej działalność upadłego banku lub wykupienie pakietu kontrolnego $\mathrm{w}$ upadającej instytucji i restrukturyzacja mająca na celu sprywatyzowanie w niedalekiej przyszłości. Główną zasadą pomocy, bez względu na sposób jej udzielania jest zasada najmniejszego kosztu dla konsumenta lub podatnika.

Jak wskazuje J. Pruski oraz J. Szambelańczyk [2014], kraje w których instytucje gwaranta są silnię legislacyjnie, kapitałowo i organizacyjnie, częściej występują modele typu ,risk minimiser”, wraz z wymienionymi wyżej instrumentami. Poszerzenie instrumentów mających na celu ustabilizowanie sektora bankowego wiąże się z pewnymi konsekwencjami, przede wszystkim wspomnianym wcześniej problemem pokusy nadużycia. Pojawiają się one wśród banków, które zdają sobie sprawę, że w przypadku bardziej ryzykownej akcji kredytowej nie zbankrutują, a nawet mogą mieć dostęp do atrakcyjnej pomocy finansowej. Kolejnym, równie istotnym problemem, także związanym z pomocą finansową, jest próba samego zaniechania likwidacji podmiotu. Wiąże się to z koncepcją „kreatywnej destrukcji” J. A. Schumpeter'a, czyli naturalnej likwidacji przedsiębiorstw, które nie utrzymały przewagi strategicznej ze względu na niedostosowanie do zmian zachodzących $\mathrm{w}$ gospodarce i tym samym zwolniły miejsca bardziej innowacyjnym przedsięwzięciom. Według J.A. Schumpetera, tego rodzaju transformacja struktury gospodarki jest skutkiem innowacji oraz jest konieczna dla rozwoju gospodarczego [Schumpeter 2009].Według danych z 2013 roku około $43 \%$ wszystkich systemów gwarancji depozytów spełniało funkcje typu ,paybox", natomiast 56\% posiadało większy zakres obowiązków [Deposit Insurance dataset/World Bank 2013].

\subsection{Finansowanie funduszu gwarancyjnego}

Oczywiście system gwarancji depozytów nie mógłby spełniać swojej podstawowej funkcji bez uzyskania niezbędnych środków. Większość aktywności wiąże się z finansami, dlatego każdy system wymaga adekwatnej ilości kapitału, aby w odpowiednim stopniu zapewnić stabilność sektora finansowego.

Pierwszym oraz najmniej spotykanym źródłem finansowania funduszu gwarancyjnego jest budżet państwa. W tym przypadku sektor finansowy nie ponosi bezpośrednio żadnych kosztów związanych z problemami pojedynczych instytucji finansowych, tym samym jest w pełni beneficjentem tego systemu. Wiąże się 
to z dyskusją, czy można to zaliczyć do pomocy publicznej, która jest zakłóceniem zasad wolnej konkurencji.

Najpopularniejsze źródło finansowania wiąże się z koncepcją solidarności branży. Wszystkie fundusze są pobierane bezpośrednio z sektora prywatnego, najczęściej od podmiotów objętych gwarancją. To rozwiązanie przyczynia się do ograniczenia pokusy nadużycia oraz nie przenosi kosztów błędnego zarządzania na podatników.

Połączeniem dwóch poprzednich sposobów, jest mieszane źródło finansowania, w którym składki są podzielone między państwo i sektor prywatny. Rozwiązanie to jest często wprowadzane, gdy zasoby zebrane z sektora finansowego nie są wystarczające w stosunku do potrzeb depozytariuszy lub gdy sektor finansowy nie jest odpowiednio rozwinięty, żeby przyjąć na siebie całość kosztów prowadzenia systemu gwarancji depozytów.

W roku 2013 tylko 2 państwa (Australia i Chile) miały fundusz finansowany ze środków publicznych $(1,8 \%), 87$ państw $(78 \%)$ zbierało środki wyłącznie z sektora prywatnego oraz w 22 państwach $(19,8 \%)$ finansowanie było wspólnie [Deposit Insurance dataset/World Bank 2013].

Dodatkową kwestią finansowania systemów gwarancji depozytów jest czas, w którym zbierane są środki na pokrycie depozytów. Jednym z dwóch sposobów jest ex ante, czyli finansowanie funduszu co wyznaczony okres przez każdy podmiot objęty gwarancją, nawet pomimo braku jakiegokolwiek bankructwa instytucji finansowej. Korzyści tego sposobu finansowania są dosyć jasne środki na pokrycie depozytów mogą być w każdym momencie wypłacone, koszty sektora finansowego są przewidywalne oraz panuje wśród konsumentów poczucie bezpieczeństwa, ze względu na dyspozycyjność środków gwarantujących.

Finansowanie może także przebiegać w sposób ex post, czyli w momencie, gdy zajdzie potrzeba wypłacenia środków depozytariuszy. Najistotniejszą cechą w tym przypadku jest brak kosztów działalności systemów gwarancji depozytów w przypadku braku upadłości instytucji przyjmującej depozyty. Negatywnym aspektem tego finansowania jest jego procykliczny charakter. W przypadku trudnego otoczenia makroekonomicznego banków, są one poddawane dodatkowo wyższym kosztom z tytułu wypłacania depozytów instytucji upadających. Ta słabość jest także atutem finansowania ex ante, w którym koszty są rozłożone przez cały okres cyklu koniunkturalnego równomiernie.

Przewagę finansowania ex ante widać także w statystykach. Według danych z 2013 roku aż 88\% systemów przyjęło taką kolej zbierania funduszy, natomiast reszta była finansowana w sposób ex post [Deposit Insurance dataset/World Bank 2013]. Koszty banków związane z finansowaniem systemu gwarancji depozytów, ze względu na odmienne skale prowadzonej działalności, są różnicowane. Wykorzystuję się konkretne podstawy do ich obliczania tak, żeby każda instytucja płaciła adekwatną do swojej działalności opłatę. 
W trakcie adaptacji systemów gwarancji depozytów uwidoczniły się cztery główne rodzaje przyznawania wielkości składki do funduszu gwarancyjnego, a każdy z nich opiera się na pozycji bilansu instytucji finansowej. Podstawy opłat to:

- Pokryte depozyty - opłata według tej bazy jest liczona jako procent depozytów, które są gwarantowane przez system gwarancji, po uwzględnieniu poziomu pokrycia.

- Kwalifikujące depozyty - suma depozytów kwalifikujących się do gwarancji, czyli przed uwzględnieniem poziomu pokrycia.

- Suma depozytów - suma wszystkich depozytów, w tym tych, które nie są gwarantowane przez fundusz gwarancyjny.

- Suma zobowiązań - suma wszystkich zobowiązań finansowych instytucji objętej gwarancją.

Każda z podstaw przyjętych opłat ma na celu sprawiedliwość funkcjonowania systemu gwarantowania depozytów oraz uniknięcie przewyższenia osiąganych korzyści z gwarancji depozytów nad kosztami jego funkcjonowania przez instytucję finansową, czyli tak zwanego efektu gapowicza.

Relatywnie nowym rozwiązaniem jest płacenie premii za zwiększone ryzyko prowadzonej działalności. Ma to przede wszystkim na celu zmniejszenie pokusy nadużycia oraz wyeliminowanie zjawiska subsydiowania krzyżowego (ang. cross subsidization), które przejawia się w tym przypadku przenoszeniem korzyści z instytucji niepoddającym się nadmiernemu ryzyku do tych, które działają bardziej ryzykownie. Takie rozwiązanie zostało przyjęte pierwszy raz w Stanach Zjednoczonych w 1993 roku, jako odpowiedz na kryzys instytucji oszczędnościowo-kredytowych (ang. savings and loan crisis).

Aktualnie w ramach premii za ryzyko amerykański FDIC (ang. Federal Deposit Insurance Corporation) dzieli instytucje na 4 grupy ryzyka według ich wskazników kapitałowych oraz ustala na ich podstawie adekwatną opłatę [www8].

Według danych z 2013 roku, 31\% systemów przyjęło płacenie premii za prowadzone ryzyko [Deposit Insurance dataset/World Bank 2013], natomiast po wprowadzeniu Dyrektywy Parlamentu Europejskiego i Rady 2014/49/UE, która zobowiązuje państwa członkowskie do zastosowania tego rodzaju podstaw odprowadzania składek, udział tych systemów się zwiększał.

\subsection{Poziom pokrycia depozytów}

Najbardziej interesującym konsumentów oraz najistotniejszym parametrem rozrózniającym systemy gwarancji depozytów jest zadeklarowany poziom pokrycia depozytów. W każdym państwie, w którym znajduje się system typu explicite, 
określa się limit pokrycia oraz ewentualną koasekurację depozytu. Zbyt wysoki limit może byc ciężarem dla sektora finansowego lub budżetu mniej rozwiniętych państw. Natomiast za niski, może podważyć zaufanie do systemu bankowego oraz - jak zaznacza M. Zaleska [2013] - zmniejszyć atrakcyjność sektora bankowego w porównaniu do sąsiadujących państw, co może prowadzić także do ograniczenia płynności instytucji kredytowych, tak jak miało to miejsce w ostatnim kryzysie finansowym. Z tego samego powodu Unia Europejska podejmuje odpowiednie działania prawne mające na celu skoordynowanie poziomu pokrycia [Dyrektywa Parlamentu Europejskiego i Rady 2014/49/UE].

Koasekuracja to część limitu depozytu, który zostaje stracony przez depozytariusza w wypadku bankructwa instytucji i ma ona na celu zmobilizowanie do monitorignu sytuacji finansowej instytucji przyjmującej depozyt przez powierzających jej środki klientów.

W okresie kryzysów gospodarczych, stosuję się także pełne pokrycie depozytów (między innymi w Japonii w 1996 roku). Aby uniknąc procykliczności, wynikającej ze zwiększonej potrzeby finansowania, najczęściej jest pokrywany przez sektor publiczny.

Wysokość limitu jest bardzo zróżnicowana, od 23,204 USD w Albanii, do tak wysokich jak 258,771 USD w Norwegii ${ }^{1}$. Różni się to w dużej mierze z powodu wielkośći gospodarki, sektora finansowego oraz siły nabywczej kraju. Limit wyrażony w dolarach jest bardzo syntetyczny, natomiast aby lepiej poznać wysokość gwarancji należy przedstawić ją na tle wielkości gospodarki. Użyteczny do tego jest stosunek limitu gwarancji depozytów do PKB per capita, wyrażonego w parytecie siły nabywczej (PPP) - dla Albanii wynosi on 2.03, natomiast dla Norwegii 4.05 [www7]. W miernikach relatywnych do wielkości gospodarki nie widać tak drastycznych różnic. W roku 2013 pokryte depozyty średnio stanowiły 6,89-krotność PKB per capita krajów. Co ciekawe, w przypadku państw nisko-średniego dochodu (ang. lower middle income) wskaznik ten stanowił aż 11-krotność [Deposit Insurance dataset/World Bank 2013]. Warto również spojrzeć na stosunek wielkości zebranych środków w funduszu gwarancyjnym do sumy gwarantowanych depozytów - w Albanii wynosi on 4,56\%, natomiast w Norwegii 2,5\% [The Norwegian's Bank Guarantee Fund Annual Report 2016; Albanian Deposit Insurance Agency Annual Report 2015]. Wskazuje on nam zdolność funduszu do spełniania jego głównej działalności, czyli wypłacania depozytów straconych przez brankrutującą instytucję.

W przypadku państw Unii Europejskiej wskaźnik ten musi wynosić do 3 lipca 2024 r. minimalnie 0,8\% [Dyrektywa Parlamentu Europejskiego i Rady 2014/49/UE].

${ }^{1}$ ALL/USD - 0.00928198, NOK/USD - 0.129386, na dzień 25 stycznia 2018 roku wg. witryny www.xe.com. 


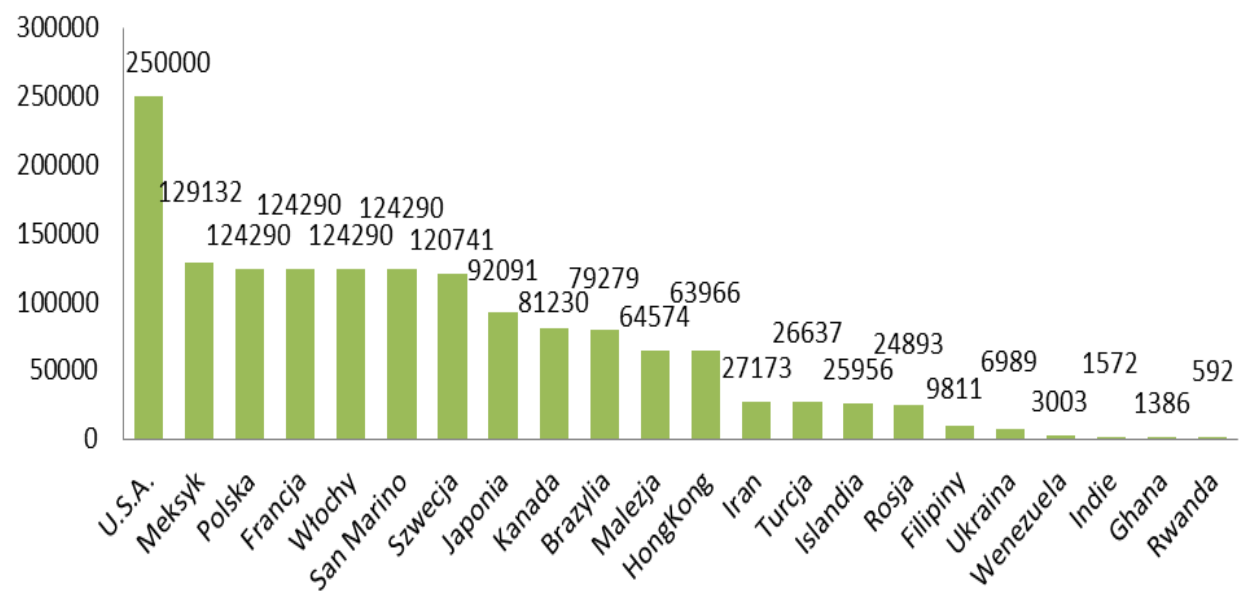

Wykres 2. Poziomy pokrycia depozytów na świecie. Dane w USD na dzień 26 stycznia 2018 roku wg. witryny www.xe.com

Źródło: opracowanie własne na podstawie informacji z oficjalnych stron oraz dokumentów funduszy gwarancyjnych depozytów [www10].

\section{PODSUMOWANIE}

Na świecie można dostrzec wyraźny postęp konwergencji pod względem adaptacji systemów gwarancji depozytów, który wraz z rozwojem krajów niskiego dochodu, najpewniej będzie kontynuowany. W przeciągu ostatnich 5 lat znaczna większość systemów gwarantowania depozytów typu explicite, zostało przyjęte w krajach niskiego i nisko-średniego dochodu. Podobnie to wygląda dla systemów, które są aktualnie tworzone. W przypadku Europy zdecydowanie widać wpływ dyrektywy w sprawie systemów gwarantowania depozytów, między innymi w przyjętym limicie gwarancji depozytów oraz finansowaniu funduszu. Niemniej jednak te podobieństwa nadal pozostają niewystarczające do bezproblemowego wprowadzenia paneuropejskiego systemu gwarancji depozytów, który był jednym z ważniejszych części, zaproponowanej już w 2012 roku przez przewodniczącego Rady Europejskiej, idei europejskiej unii bankowej [Zaleska 2013]. Pomimo tak istotnych odzewów ze strony Unii Europejskiej, kraje nie spieszą się z przyjmowaniem identycznych rozwiązań w zakresie systemów gwarancji depozytów.

Zgodnie z hipotezą można zauważyć, że formy przyjętych systemów gwarancji depozytów różnią się w zależności od etapu konwergencji gospodarczej kraju. We wczesnym etapie posiadają systemy typu implicite i wraz z rozwojem 
formalizują je, ustanawiając instytucje, które najczęściej pozostają w strukturze innej instytucji publicznej. Natomiast systemy gwarantowania depozytów w krajach rozwiniętych przyjmują rozwiązania z myślą o utrzymaniu dyscypliny sektora na jak najwyższym poziomie, poprzez takie rozwiązania jak na przykład oparcie składek o poziom ryzyka instytucji kredytowych.

Przy tworzeniu systemu gwarancji depozytów, większość podejmowanych decyzji ma charakter „,coś za coś”. Z jednej strony można przyjąć system idealnie chroniący podmioty sektora finansowego, pomagający za każdym razem, gdy tylko jakakolwiek instytucja będzie zagrożona niewypłacalnością oraz dający nieograniczony limit gwarancji dla każdego depozytariusza. Niestety może mieć to dosyć poważne konsekwencje dla dyscypliny sektora finansowego oraz istotnie ograniczyć rozwój gospodarczy. Trzeba znaleźć złoty środek chroniący konsumentów na rynku usług finansowych oraz nieograniczający potencjału rozwoju sektora finansowego.

\section{BIBLIOGRAFIA}

Albanian Deposit Insurance Agency Annual Report, 2015.

Baka W. (red.), 2005, Systemy gwarantowania depozytów w Polsce i na świecie: dziesięć lat Bankowego Funduszu Gwarancyjnego, PWE, Warszawa.

Bernanke B., 1995, The Macroeconomics of the Great Depression: A Comparative Approach, „Journal of Money, Credit, and Banking”, vol. 27.

Demirgüç-Kunt A., Detragiache E., 2000, Does Deposit Insurance Increase Banking System Stability?, World Bank, Development Research Group and International Monetary Fund, Research Department.

Demirgüç-Kunt A., Kane E.J., Laeven L., 2006, Determinants of Deposit-Insurance Adoption and Design, „Policy Research Working Paper”, vol. 1.

Deposit Insurance dataset/World Bank, 2013.

Diamond D., 1983, Banks and Liquidity Creation: A Simple Exposition of the Diamond-Dybvig Model.

Drabik E., 1998, Elementy teorii gier dla ekonomistów, Wydawnictwo Uniwersytetu w Białymstoku, Białystok.

Dyrektywa Parlamentu Europejskiego i Rady 2014/49/UE z dnia 16 kwietnia 2014 roku.

IADI, 2016, Annual Survey.

IMF, 2016, Raport krajowy, 16/96.

IMF, Mozambique: Fiscal Transparency Evaluation.

International Monetary Fund, Bolivia: Sixth Review Under the Stand-By Arrangement and Requests (...) and Statement by the Executive Director for Bolivia, 2005.

Keynes J.M., 1936, The General Theory of Employment, Interest and Money.

Kroszner, R.S., Stratmann T., 1998, Interest Group Competition and the Organization of Congress: Theory and Evidence from Financial Services' Political Action Committees, „American Economic Review", vol. 88.

Lubiński M., 2014, Zarażenie w systemie bankowym - przyczyny i mechanizmy, „Prace i Materiały Instytutu Rozwoju Gospodarczego SGH”, nr 94. 
Modan C., Hassan R., 2015, Legal and Financial Regulatory Framework of Mozambique: The Possible Inclusion of Islamic Banking and Finance, Islamic Research and Training Institute.

Monetary Authority of Brunei Darussalam, 2010, Brunei Darussalam Financial Sector Blueprint the isle of Man Financial. Services Authority, Depositors' Compensation Scheme Regulations.

National Assembly of Pakistan, 2016, The Deposit Protection Corporation Act.

Patterson R., 2015, Kompendium terminów z zakresu bankowości po polsku i angielsku, Ministerstwo Finansów, Warszawa.

Pawlikowski A., 2005, The Polish deposit insurance scheme compared to arrangements adopted in other EU countries, NBP Working Papers 34, Narodowy Bank Polski, Economic Research Department.

Pruski J., Szambelańczyk J., 2014, Bezpieczny bank, Systemy gwarantowania depozytów w sieciach bezpieczeństwa finansowego na tle konsekwencji globalnego kryzysu finansowego, „Bezpieczny Bank”, nr 4(57).

Samuelson P., Nordhaus W.D., 2012, Ekonomia, Rebis, Warszawa.

Schumpeter J.A., 2009, Kapitalizm, socjalizm, demokracja, Wydawnictwo Naukowe PWN, Warszawa.

The Norwegian's Bank Guarantee Fund Annual Report, 2016.

[www1] https://www.channel4.com/news/the-great-northern-rock-bank-run.

[www2] https://www.ft.com/content/92281bda-8a3b-11dd-a76a-0000779fd18c.

[www3] International Association of Deposit Insurers (IADI).

[www4] www.bcsm.sm/site/en/home/functions/other-functions/guarantee-fund-fordepositors.html, www.bnr.rw/index.php?id=331, www.bog.gov.gh/whars-new/3373-ghanadeposit-protection-corporation, www.frbsf.org/banking/asia-program/pacific-exchangeblog/regional-comparison-chinas-new-deposit-insurance-system/en.idgf.ir, www.cdic.gov.tw, www.bancentral.gov.do/sistema_financiero/fondo_contingencia/, www.dcs.gg/about-the-scheme/, www.iomfsa.im/consumer-material/isle-of-man-depositorscompensation-scheme-dcs/,

www.gov.je/Industry/Finance/DepositProtection/Pages/Overview.aspx,

www.bcm.com.mo/en/notice1.php, www.pdic.ps, www.amcm.gov.mo/en/about-

amcm/organization-structure/fundo-de-garantia-de-depositos.

[www5] www.dic.go.jp, www.oba.hu, www.protectionfund.be.

[www6] www.fovsr.sk, https://www.eas-liechtenstein.li/en/.

[www7] www.bankenessikringsfond.no/deposit-guarantee/category949.html,

www.fsd.org.pe/english/01-ENG-acerca-del-FSD/01-01-ENG-Antecedentes.html.

[www8] www.fdic.gov.

[www9] pl.tradingeconomics.com.

[www10] www.fdic.gov, www.ipab.org.mx, bfg.pl, www.garantiedesdepots.fr, www.fitd.it/, www.bcsm.sm/site/en/home/functions/other-functions/guarantee-fund-for-depositors.html, www.riksgalden.se, www.dic.go.jp, www.cdic.ca, www.fgc.org.br, www.pidm.gov.my, www.dps.org.hk, en.idgf.ir, www.tmsf.org.tr, www.tryggingarsjodur.is, www.asv.org.ru, www.pdic.gov.ph, www.fg.gov.ua, www.fogade.gob.ve, www.dicgc.org.in, www.bog.gov.gh, www.bnr.rw.

Zaleska M., 2013, Unia bankowa, Difin, Warszawa. 


\title{
DEPOSIT INSURANCE SCHEMES AROUND THE WORLD - COMPARATIVE ANALYSIS
}

\begin{abstract}
The purpose of this article is to show and compare various types or arrangements, adopted around the world and their implications on financial system. The article presents theoretical aspects of deposit insurance schemes functioning, which gives rudiments for reader to judge different arrangements shown in further part of the article. In this article, author characterized various features, such as : formalization, structure and administration, limit of deposit coverage, funding and also its role. Every description is presented with economic issue that given arrangement is related to and contains examples of countries where it exists. Empirical data is taken from World Bank dataset and IADI, in many cases updated with information from official websites or documents of deposit guarantee schemes or institutions that are responsible for them and working papers.
\end{abstract}

Keywords: banking, deposit guarantee scheme, deposit insurance, financial stability, moral hazard, banking sector stability, banking deposit, consumer protection, deposit protection, banking services, financial theory. 